\title{
Pengaruh Metode Sosiodrama Terhadap Kemampuan Memahami Isi Bacaan pada Siswa Tunarungu di SMPLB
}

\author{
Risma Laurentia Putri, Mohammad Efendi, Sihkabuden \\ Universitas Negeri Malang \\ Email : rismalaurentia07@gmail.com
}

\begin{abstract}
Abstrak: Ketidakberfungsian organ pendengaran pada tunarungu mengakibatkan terhambatnya perkembangan bahasa dan bicara sehingga pada anak tunarungu mengalami hambatan dalam memperoleh informasi. Tujuan penelitian ini adalah untuk mengetahui adanya perbedaan kemampuan memahami isi bacaan sebelum dan sesudah diberikan treatment berupa metode sosiodrama pada siswa tunarungu kelas VII di SMPLB Bhakti Wanita Lumajang. Hasil penelitian menunjukkan perolehan rata-rata pada tahap pre test sebesar 42,5 , sedangkan perolehan rata-rata pada tahap post test meningkat sebesar 79,5 setelah dilakukan intervensi.
\end{abstract}

Kata kunci: sosiodrama, kemampuan memahami isi bacaan, tunarungu

abstract: Dysfunctional hearing organ to the deaf people result in late development of language and speaking, thus deaf children have obstacles in getting information. The objective of this research as follows: (1) to know the effect towards the use of sociodrama method to the ability in understanding reading content for deaf students in 7th Grade SMPLB (Junior High School of Special Education) Bhakti Wanita Lumajang. The research result showed that average score in pre test was 42,5 , while in the post test the average score improved to be 79,5 after conducted by intervention.

Keywords: sociodrama, ability in understanding reading content, deaf

Bahasa merupakan sarana yang sangat penting dalam kehidupan kita karena bahasa merupakan alat untuk menyatakan pikiran dan perasaan kepada orang lain, untuk mengembangkan ekspresi, dan juga untuk mengembangkan kemampuan intelektual seseorang. Indera pendengaran berperan penting bagi manusia sebagai indera yang digunakan untuk memperoleh informasi dari lingkungan. Berbeda halnya dengan anak tunarungu. Winarsih (2007), menyatakan tunarungu adalah seseorang yang mengalami kekurangan atau kehilangan kemampuan mendengar baik sebagian atau seluruhnya yang diakibatkan oleh tidak berfungsinya sebagian atau seluruh alat pendengaran, sehingga anak tersebut tidak dapat menggunakan alat pendengarannya dalam kehidupan sehari-hari. Hal tersebut berdampak terhadap kehidupannya secara kompleks terutama pada kemampuan berbahasa sebagai alat komunikasi yang sangat penting. Ketidakberfungsian organ pendengaran pada tunarungu mengakibatkan terhambatnya perkembangan bahasa dan bicara sehingga pada anak tunarungu mengalami hambatan dalam memperoleh informasi. Menurut Pradipta (2017) Penguasaan struktur kalimat merupakan hal yang sangat penting, karena dengan struktur kalimat yang benar maka makna dari sebuah kalimat bisa dipahami, di samping itu komunikasi menjadi lebih efektif dan efisien tidak terkecuali siswa tunarungu.

Sehubungan dengan hal tersebut, siswa tunarungu perlu dibekali pengajaran memahami suatu isi bacaan. Tujuan pengajarannya adalah untuk meningkatkan kemampuan memahami isi bacaan. Adapun pembelajaran memahami isi bacaan yang diberikan berisi kegiatan membaca, menjawab pertanyaanpertanyaan yang sesuai dengan isi bacaan, dan mampu menceritakan kembali isi bacaan serta mampu membuat kesimpulan sesuai materi yang diajarkan.

Pada dasarnya siswa tunarungu memiliki kecerdasan yang normal jika tidak disertai dengan hambatan intelektual. Namun tetap saja kemampuan siswa tunarungu lebih rendah dibandingkan dengan anak normal pada umumnya. Dalam menangani hal ini, siswa tunarungu harus difasilitasi dengan metode, media, dan materi yang sesuai dengan kebutuhan siswa. Informasi yang diberikan pada siswa tunarungu hendaknya tidak bersifat abstrak. Siswa tunarungu kurang dalam kemampuan memahami isi bacaan, ketika bacaan tidak diperjelas dengan informasi yang bersifat konkret. Sebagai salah satu solusinya, guru dapat menggunakan metode, karena kondisi psikologis siswa tunarungu.

\section{METODE}

Penelitian ini menggunakan metode eksperimen dengan desain one group pretest-posttest. Eksperimen merupakan cara untuk mencari hubungan sebab akibat dua faktor yang sengaja ditimbulkan peneliti dengan mengurangi atau menyisihkan faktor lain yang dapat menganggu. Eksperimen dilakukan dengan maksud untuk mengetahui akibat drai suatu perlakuan (Arikunto, 2013). 
Tabel 1 Nama siswa

\begin{tabular}{llll}
\hline No & Nama Siswa & Nilai & Rata-rata \\
\hline 1. & Ahmad H & 30 & \\
2. & Faizul & 50 & \\
3. & Fanni P. N. & 40 & 42,5 \\
4. & Nur R & 47,5 & \\
5. & Wahyu S. & 45 & \\
\hline \multicolumn{4}{r}{ Jumlah } \\
\hline
\end{tabular}

Tabel 2 Rekapitulasi Hasil Nilai Pretest dan Post Test

\begin{tabular}{|c|c|c|c|c|}
\hline No & Nama Siswa & $\begin{array}{l}\text { N i l a i } \\
\text { Pre test }\end{array}$ & $\begin{array}{l}\mathrm{N} \text { i } 1 \text { a i } \\
\text { Post Test }\end{array}$ & $\begin{array}{l}\text { Perub } \\
\text { ahan } \\
\text { Tanda }\end{array}$ \\
\hline 1. & Ahmad H. & 30 & 80 & + \\
\hline 2. & Faizul & 50 & 82,5 & + \\
\hline 3. & Fanni P. N. & 40 & 82,5 & + \\
\hline 4. & Nur R. & 47,5 & 77,5 & + \\
\hline 5. & Wahyu S. & 45 & 75 & + \\
\hline \multicolumn{2}{|c|}{ Jumlah } & 212,5 & 397,5 & \\
\hline \multicolumn{2}{|c|}{ Rata-rata } & 42,5 & 79,5 & \\
\hline
\end{tabular}

\section{Gambar 1 Hasil Pretest dan Post Test}

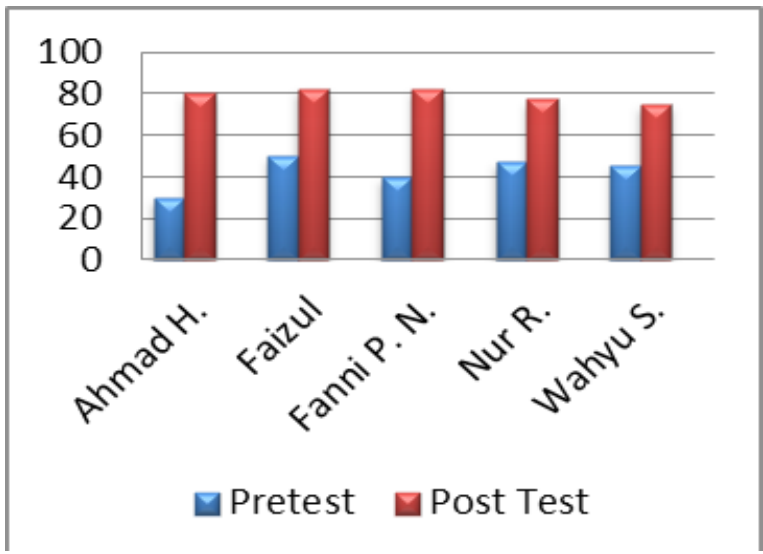

Teknik pengumpulan data yang dilakukan dalam penelitian ini adalah dengan menggunakan metode tes berupa tes kemampuan memahami isi bacaan pada pelajaran bahasa Indonesia. Tes tulis adalah kegiatan siswa mengerjakan soal untuk mengukur seberapa jauh pengetahuan siswa.

Dalam penelitian ini sampel yang digunakan berjumlah 5 anak dengan jenis ketunaan tunarungu. Setiap siswa memiliki karakterisktik yang berbeda. Salah satu karakteristik yang terlihat jelas yaitu kurang percaya diri pada anak, salah satu contoh pada saat peneliti menyuruh salah satu anak untuk menyampaikan kesimpulan dari suatu bacaan anak tersebut ragu dalam menyampaikan. Karakter lain yang dimiliki anak tunarungu yaitu dilihat dari cara berkomunikasi dengan peneliti.

\section{HASIL DAN PEMBAHASAN}

\section{Hasil}

Kemampuan awal siswa (pretest) sebelum menggunakan metode sosiodrama. Data tentang kemampuan awal diperoleh dari hasil tes kemampuan awal yang dilakukan pada hari selasa 13 Juni 2017. Tes kemampuan awal ini dilakukan dengan memberikan soal tes pada anak berupa tugas membaca, essay, tes performance, dan uraian. Berdasarkan tabel 1 dapat diketahui hasil pretest kemampuan awal siswa dalam memahami isi bacaan yakni siswa yang mendapat rentang nilai 0-39 berjumlah 1 siswa, sedangkan yang mendapat rentang nilai 40-55 berjumlah 4 siswa, dan siswa yang mendapat rentang nilai 56-65, rentang nilai 66-79, dan rentang nilai $80-100$ berjumlah 0 siswa. Kemampuan akhir siswa (post test) setelah menggunakan metode sosiodrama. Setelah dilakukan pemberian treatment menggunakan metode sosiodrama pada tanggal 14 Juni 2017 sampai 15 Juni 2017, maka tahap selanjutnya adalah dengan memberikan post test. Test ini dilakukan untuk mengetahui kemampuan siswa dalam memahami isi bacaan setelah melakukan metode sosiodrama. Hasil kemampuan memahami isi bacaan siswa tunarungu pada tahap post test sebagai berikut :

Berdasarkan tabel 2 dapat diketahui hasil pretest kemampuan awal siswa dalam memahami isi bacaan yakni siswa yang mendapat rentang nilai 0-39 berjumlah 0 siswa, mendapat rentang nilai $40-$ 55 berjumlah 0 siswa, dan siswa yang mendapat rentang nilai $56-65$ berjumlah 0 siswa, sedangkan yang mendapatkan rentang nilai 66-79 berjumlah 2 siswa, dan rentang nilai 80-100 berjumlah 3 siswa. Setelah mengetahui hasil nilai pretest dan post test, selanjutnya dilakukan rekapitulasi yang berguna untuk mengetahui ada tidaknya peningkatan kemampuan memahami isi bacaan setelah diajarkan menggunakan metode sosiodrama. Berikut disajikan rekapitulasi hasil nilai pretest dan post test:

Adapun diagram batang hasil nilai pretest dan posttest kemampuan memahami isi bacaan siswa tunarungu kelas VII SMPLB Bhakti Wanita Lumajang sebelum dan sesudah menerapkan metode psikodrama dapat disajikan pada tabel 2. Hasil pretest dan post test yang disajikan melalui data gambar 1 dapat disimpulkan bahwa nilai rata-rata pretest lebih rendah dari pada nilai post test. Perbedaan nilai ratarata tersebut menunjukkan bahwa terdapat perbedaan 
kemampuan memahami isi bacaan pada kegiatan pembelajaran sebelum dan setelah menerapkan metode sosiodrama.

\section{Pembahasan}

Kemampuan Memahami Isi Bacaan Siswa Tunarungu Kelas VII SMPLB Bhakti Wanita Lumajang Sebelum Diberikan Treatment

Pelaksanaan kegiatan pembelajaran pada penelitian ini dilakukan pada siswa tunarungu kelas VII SMPLB Bhakti Wanita Lumajang dengan jumlah 5 siswa. Kondisi awal sebelum diberikan treatment, kemampuan siswa sangat rendah. Siswa masih kebingungan dan sering bertanya mengenai soal yang diberikan peneliti. Hal ini ditunjukkan pada saat siswa mengerjakan soal pre test. Hal tersebut dapat dilihat dari jawaban siswa yang kurang tepat dan belum memahami bacaan. Kemampuan awal siswa juga menunjukkan bahwa hasil belajar dalam memahami isi bacaan belum mencapai kriteria ketuntasan minimal yang ditentukan sekolah yaitu 60 .

Terbatasnya ketajaman pendengaran pada abak tunarungu mengakibatkan tidak terjadinya proses peniruan suara. Setelah masa meraban, proses peniruannya hanya terbatas pada peniruan visual. Selanjutnya dalam perkembangan bahasa dan bicara, anak tunarungu memerlukan pembinaan secara khusus dan intensif sesuai dengan kemampuan dan taraf ketunarunguannya. Haenudin (2013) menyebutkan tunarungu dalam segi bahasa memiliki ciri yang khas, yaitu sangat terbatas dalam pemilihan kosa kata, sulit mengartikan arti kiasan dan kata-kata yang bersifat abstrak.

Kemampuan Memahami Isi Bacaan Siswa Tunarungu Kelas VII SMPLB Bhakti Wanita Lumajang Setelah Diberikan Treatment Kondisi siswa tunarungu kelas VII SMPLB Bhakti Wanita Lumajang dalam pembelajaran memahami isi bacaan setelah diberikan treatment meningkat, lebih baik dibandingkan dengan kondisi awal sebelum diberikan treatment. Dalam mengerjakan soal post test siswa tunarungu lebih aktif dan lebih percaya diri, mereka hanya mengeluarkan sedikit pertanyaan saja. Penggunaan metode ajar yaitu metode sosiodrama salah satu metode yang digunakan dalam proses belajar. Metode yang digunakan dalam menanamkan pemahaman siswa tunarungu terhadap bacaan yang representasikan lewat pengalaman siswa secara langsung. Hal ini sesuai dengan pendapat yang disampaikan oleh Zuchdi (2008) bahwa dalam membaca pemahaman selain melibatkan bahasa, motivasi, persepsi, pengembangan konsep, juga melibatkan keseluruhan pengalaman. Penggunaan metode sosiodrama mampu mengurangi ketidakpahaman siswa mengenai penjelasan isi cerita. Penggunaan metode sosiodrama bagi siswa tunarungu menunjukkan kemampuan pemahaman hal-hal terkait dengan rincian isi cerita. Selain itu memberikan daya tarik, memunculkan minat belajar pada siswa dalam memahami bacaan dapat teratasi.

Berdasarkan hasil analisis post test dapat diketahui bahwa kemampuan siswa tunarungu dalam memahami isi bacaan masuk dalam kriteria cukup mampu.

Berdasarkan hasil analisis data antar kondisi, peningkatan kemampuan memahami isi bacaan siswa tunarungu ditandai dengan mengerjakan soalsoal dengan baik dan benar. Penelitian yang telah dilakukan ini sesuai dengan prosedur penelitian preeksperimen dengan desain one group pre-test post test design, diketahui bahwa ada pengaruh positif dari pemberian perlakuan (treatment) berupa penerapan metode sosiodrama terhadap kemampuan memahami isi bacaan pada siswa tunarungu kelas VII di SMPLB Bhakti Wanita Lumajang. Hal ini dapat diketahui berdasarkan hasil pre test dan post test, yakni nilai rata-rata pre test lebih rendah dibandingkan dengan nilai rata-rata post test. Perbedaan nilai rata-rata pre test dan post test menunjukan bahwa kemampuan memahami isi bacaan berbeda. Hal ini dikarenakan pada saat posttest menerapkan metode sosiodrama. Pada proses pengenalan dan pengajaran menggunakan metode sosiodrama kepada siswa tunarungu harus diberi penjelasan yang lebih agar mengarah pada pembelajaran ceramah, demonstrasi dan pemberian tugas. Metode ceramah adalah penerangan secara lisan atas bahan penerangan kepada sekelompok pendengar untuk mencapai tujuan pembelajaran tertentu dalam jumlah yang relatif besar.

Kata prosedur lebih bersifat teknis administratif atau taksonomis. Seolah-olah mendidik atau mengajar hanya diartikan cara mengandung implikasi mempengaruhi. Maka saling ketergantungan antara pendidik dan anak didik dalam proses kebersamaan menuju kearah tujuan tertentu sedangkan metode pemberian tugas dilakukan untuk melihat kemampuan siswa setelah menggunakan metode pembelajaran. Tugas yang disampaikan oleh peneliti mengenai kemampuan memahami isi bacaan. Fungsi dari pemberian materi ini adalah untuk mengukur sejauh mana kemampuan anak tunarungu dalam memahami isi bacaan sesuai dengan pembelajaran bahasa Indonesia.

Berdasarkan hasil analisis data yang telah dilakukan dan disajikan dalam bentuk tabel dan diagram dengan menggunakan desain one group pre test post test design, maka dapat dikatakan dengan menerapkan metode sosiodrama ini dapat meningkatkan kemampuan memahami isi bacaan siswa tunarungu kelas VII di SMPLB Bhakti Wanita Lumajang. Pada pembelajaran di kelas menerapkan metode sosiodrama siswa lebih aktif dan percaya diri. Berdasarkan pencapaian siswa tunarungu dalam 
penelitian ini menunjukkan penerapan metode sosiodrama dalam kemampuan memahami isi bacaan memuaskan bagi guru dan peneliti, karena indikator keberhasilan tercapai. Penerapan metode sosiodrama dalam proses belajar mengajar memahami isi bacaan siswa tunarungu kelas VII di SMPLB Bhakti Wanita Lumajang mendapat respon positif bagi guru maupun siswa.

\section{KESIMPULAN DAN SARAN}

\section{Kesimpulan}

Hasil peningkatan kemampuan memahami isi bacaan pada anak tunarungu kelas VII SMPLB Bhakti Wanita Lumajang dapat dilihat dari hasil tes kemampuan awal dengan nilai rata-rata 42,5 yang dikategorikan dalam kriteria tidak mampu kemudian pada tes kemampuan akhir meningkat menjadi 79,5 yang dikategorikan dalam kriteria cukup mampu. Berdasarkan hasil tersebut, terdapat pengaruh yang signifikan antara kemampuan memahami isi bacaan sebelum dan setelah diterapkan metode sosiodrama.

\section{Saran}

Bagi guru dalam menggunakan metode sosiodrama dalam pembelajaran memahami isi bacaan siswa tunarungu, guru hendaknya menciptakan suasana yang serius tapi santai, sehingga anak tidak tegang dan dapat lebih leluasa menyampaikan pendapatnya.

\section{DAFTAR RUJUKAN}

Arikunto, Suharsimi. 2013. Dasar-dasar Evaluasi Pendidikan. Jakarta: Bumi Aksara

Haenudin. 2013. Pendidikan Anak Berkebutuhan Khusus Tunarungu. Jakarta: Luxima

Pradipta, R. F., Ummah, U. S., \& Susilawati, S. Y. Pengaruh Penggunaan Media Gambar Berseri Terhadap Peningkatan Penguasaan Tata Kalimat Pada Siswa Tunarungu.

Uno. Hamzah B. 2012. Model Pembelajaran Menciptakan Proses Belajar Mengajar yang Kreatif dan Efektif. Jakarta : Bumi Aksara

Winarsih, Murni .2007. Intervensi Dini Bagi Anak Tunarungu Dalam Pemerolehan Bahasa. Jakarta:Departemen Pendidikan Nasional Direktorat Jenderal Pendidikan Tinggi Direktorat Ketenagaan.

Zuchdi, Darmiyati. 2008. Strategi Memingkatkan Kemampuan Membaca Peningkatan Komprehensi. Yogyakarta: UNY Press. 